Dr. Henri Martin on the Solutrian sculpture of Roc, Prof. H. Obermaier on the late Magdalenian art of the Grotte du 'Pendo', near Santander, and a long and very fully illustrated study by Dr. R. Forrer of the prehistoric ritual chariot and its survivals in historic times (see NaTuRE of Sept. 10, p. 404). Not only are the illustrations of each article ample, but they are also of a high quality. The price of Part 1 is $125 \mathrm{fr}$., but owing to the fact that the size of the parts will be variable, the price is not fixed. The annual subscription, however, is $250 \mathrm{fr}$. The publishers are Librairie Ermest Leroux, Paris.

\section{Prof. J. W. Gregory}

Follownag the obituary notice of Prof. J. W. Gregory by Sir John S. Flett (NATURE, June 25, p. 930) and the letter of appreciation by Prof. Bailey Willis (NATURe, Aug. 27, p. 310) we have just received a copy of an appreciation by Mr. F. Chapman, palæontologist to the Commonwealth of Australia, who was a lifelong friend of Prof. Gregory, published in the Melbourne Age for July 16. Much of Mr. Chapman's testimony is naturally concerned with Prof. Gregory's activities during the short period (1900-4) when he was professor of geology and mineralogy in the University of Melbourne. Victoria offered many fascinating geological problems ready to hand, and Prof. Gregory took advantage of these for a thorough training of his students in field work. One of his expeditions with a party of students to Central Australia resulted in his writing one of the finest geological essays, "The Dead Heart of Australia".

\section{Prehistoric Persia}

SHобLD subsequent investigation confirm the tentative attribution of a date contemporary with Susa I. to the Stratum I. in the mound now under excavation by the American Institute of Persian Art and Archæology at Damghan in northern Persia, the discovery fully justifies the claim for interest and importance made by Dr. Arthur Upham Pope in his letter to the Times of Sept. 12. He states that Dr. Erich Schmidt, field director of the expedition, has found in that stratum beautiful hand-made pottery and copper implements upon which he bases his suggested dating. He regards the lowest levels of the mound upon which the expedition is now engaged as coming very close to the fourth millennium B.c. Further evidence of this extension of the early painted pottery culture will be awaited eagerly. The important structure revealed in Stratum III., dating from about 2000 B.c., is of exceptional interest, not only on account of the singularly rich treasure of objects of high artistic merit in gold, silver, copper, and semi-precious stone, but also for the remarkable burial of a dancing girl which was found in one corner of the building. The body was laid out in dancing pose, with silver rings on the fingers, copper rings in the ears, long coiled armlets, a necklace of effigies of turtles in lapis and silver and a little copper lion, silver tubes, lapis beads, and other objects and ornaments in metal and stone. The mere catalogue of the finds calls up an intriguing picture of the magnificence of this early eastern court, of which, how- ever, the significance will be much enhanced when something more is known of its cultural and artistic affinities.

\section{Mohenjo-Daro Ideographs}

A BoLD and entirely speculative attempt to arrive at the meaning of the pictographic designs on the seals found at Mohenjo-Daro, in the valley of the Indus, is made by Sir Flinders Petrie in the course of a notice of the recently published account of the excavations on this site by Sir John Marshall, which appears in Ancient Egypt, 1932, pt. 2. Sir Flinders Petrie justifies his method of attacking the problem by taking the ideographic signs in their primary sense of 'pictures' expressive of ideas, on the grounds, first, that being engraved on stone they escaped transformation and retained their original detail, thus being comparable with the ideographic method of Egypt; and secondly, that the study of official titles and the method of writing them in Egypt has supplied parallels to what may be discerned in India. Thus the recurrence of a number of strokes suggests that parallel to an Egyptian 'Home of Four ', ' Five Men', and the like, we have a 'Hall of Four', 'Hall of Six', etc., pointing to a system of naming officials by the number holding office, like the Duumviri, Decemviri, etc., of ancient Italy. There is evidence for this method in Cappadocia. Another set of signs consists of wheels with six or four spokes, that is, chariots and wagons, signifying transport. 'Timber', 'water supply', ' an army ', 'game ', or 'hunting' are meanings suggested for other symbols, which, in combination with other signs suggesting authority, are interpreted as the designation of officials connected with departments of State ; thus, ' Officials of the Registry of Chariots'. Nearly one-half of a hundred symbols are interpreted tentatively on the presumption that they are certainly ideographic signs such as lie at the base of Egyptian, Sumerian, and Chinese writing, but at so early a stage that the forms can mostly be recognised.

\section{The 'Historical Society of Science', 1841}

In Isis for July 1932, Mr. H. W. Dickinson gives an account of the Historical Society of Science founded in London in 1840 by J. O. Halliwell and Thomas Wright. Halliwell, who was born in Chelsea on June 21, 1820, and died near Brighton on Jan. 3, 1889, was a most remarkable man, and even as a boy had a passion for collecting MSS. He matriculated from Trinity College, Cambridge, in 1837, and before he was twenty years old had written a life of Samuel Morland and edited Sir John Mandeville's "Travels". In 1839 he was elected F.S.A. and F.R.S. The prospectus of the short-lived society for the study of the history of science said that its object was " to render materials for the history of the Sciences accessible to the general reader, by the publication of manuscripts, or the reprinting of very rare works connected with their origin and progress in this country and abroad ". The Duke of Sussex became the president of the Society, and on the council were de Morgan, Palgrave, Baden Powell, Gardner Wilkinson, Prof. Robert Willis, and others. But though its start was an

$$
\text { No. 3281, VoL. 130] }
$$

